\title{
Introduction by Ira Robinson
}

Like Islam, and unlike Christianity, Judaism, as a religion, has historically placed relatively more emphasis on actions than on faith. Any understanding of Judaism as it has historically developed, therefore, must encompass its legal system, called halakhah ["the way"] through which the laws and norms by which Jews have lived their lives are expressed (Elon, Tchernovitz). Even in modern times, when the majority of Jews no longer live their lives in strict conformity with the dictates of halakhah, a comprehensive understanding of Judaism requires any investigator to take into account the myriad ways in which halakhah has influenced the ways in which Jews of all varieties have understood themselves (Katz). Nonetheless, as Gerald Blidstein has pointed out, "the academic study of halakhic thought in general" remains in an "uncultivated state" (Blidstein, 64). Prominent among the neglected areas in the study of modern Judaism are the popular halakhic codes.

In any attempt to understand halakhah and its role in Jewish history, one of the most important, though relatively underutilized, bodies of literary evidence to be consulted consists of halakhic codes (Elon). The process of codification of the vast corpus of rabbinic halakhah was the task of generations of medieval Jews, beginning in the geonic period. The major codes, beginning with that of Isaac Alfasi in the eleventh century, and ending with Joseph Caro's Shulhan Arukh in the sixteenth century have become standard elements of rabbinic education (Twersky). They have, however, not yet become an integral past of the consciousness of historians of the Jews and Judaism, certainly as compared to the responsa literature (Haas; Soloveitchik 1990; Soloveitchik 1999). One reason for this state of affairs is that responsa seem to be much closer to life "as it was lived" than codes, and thus seem to be easier of access, and more relevant as historical documents than codes. Though it is indeed true that codes tend to describe ideal rather than actual behavior, it is equally true that the very act of expressing an ideal in the form of a constitution or a code of laws is in itself a significant factor in understanding any society (Elazar, Brown and Robinson 1985).

Of all the attempts at codification of halakhah, the most generally accepted by Jews in the past several centuries has been Rabbi Joseph Caro's sixteenth century work, Shulhan Arukh, which deserves much more scholarly attention than it has up to now received, particularly with 
respect to its use in the nineteenth century polemic between Orthodoxy and Reform (Twersky). Even less well studied, but nonetheless quite significant for an understanding of the social dynamic of Jewish communities are the numerous attempts, after the general acceptance of the Shulhan Arukh, to distill the halakhah in a form which could be approached and assimilated by Jews without advanced rabbinic training for the purpose of personal guidance and study (Elon, 1207-1208). The early and midnineteenth centuries saw two significant attempts in this genre which achieved considerable popularity and readership. Thus Rabbi Abraham Danzig (1748-1820) wrote his Hayyei Adam (Vilna, 1810), and Hokhmat Adam (Vilna, 1812) for just such a purpose. A similar attempt was that of Solomon Ganzfried (1804-1886), who published his Kitzur Shulhan Arukh in 1864 (Friedman). Nonetheless, it is generally accepted that the greatest and most influential attempts to create a cogent and accessible halakhah in the modern period are Mishnah Berurah [A Clear Teaching], ${ }^{1}$ a commentary on Shulhan Arukh by Rabbi Israel Meir ha-Kohen Kagan (1838-1933), ${ }^{2}$ and Arukh Hashulhan, by Rabbi Yechiel Mechel Halevi Epstein, the subject of the present book. However, despite these works' prominence, and their significant influence on contemporary Orthodox Judaism, their intellectual origins have hitherto not been dealt with sufficiently. It is therefore of great importance that Simcha Fishbane, after devoting serious work to Mishnah Berurah earlier in his career, has devoted intensive study to the Arukh Hashulhan. In his analysis of Rabbi Epstein's halakhic magnum opus, Fishbane rightly devotes much effort to comparing Arukh Hashulhan and Mishnah Berurah in terms of their respective halakhic methodologies, and responses to the needs of the Jewish community in the late nineteenth and early twentieth centuries. While I am unable to add to Fishbane's most useful social anthropological analysis of Rabbi Epstein, I would like to add, in the spirit of Fishbane's work, some additional perspective on Rabbi Kagan.

It is my contention that situating the intellectual origins of Mishnah Berurah becomes much easier and clearer after a close examination of two halakhic works written by Rabbi Kagan which have achieved less lasting prominence, but which chronologically immediately preceded

$1 \quad$ It was originally published in six volumes between the years 1883 and 1907. On the character and significance of this work, see Fishbane 1991. Fishbane has concentrated his study, which was originally a Concordia University doctoral dissertation, on the rhetoric of Mishnah Berurah.

2 Rabbi Kagan has not to date been well served by his biographers, whose work has tended toward hagiography. See Yoshor, Eckman. Cf. also Robinson 1985. 
the composition of his Mishnah Berurah. They are his Mahane Yisrael [The Camp of Israel] (1881), ${ }^{3}$ and Nidhe Yisrael [The Dispersed of Israel] (1893). ${ }^{4}$ These two works were not addressed by Rabbi Kagan to all faithful Jews, as was Mishnah Berurah. They were rather targeted at two groups of "anomalous" Jews: those who found themselves drafted into the Russian Army, and Jewish emigrants from Russia to America and other far off lands, respectively. In attempting to address the halakhic situation of these two groups of Jews, whose situation was common insofar as both groups found themselves separated from Jewish communities with established rabbinic leadership, Rabbi Kagan found that he had to address numerous complex legal issues with a simplicity and clarity which would become the hallmark of his later, more comprehensive halakhic work.

Rabbi Kagan, like Rabbi Epstein, wrote these two halakhic works in the context of a Russian Jewry caught up in the throes of modernization (Stanislawski 1988a; Zipperstein). Later than in Western Europe, but for many of the same reasons, Russian Jews in the latter part of the nineteenth century found themselves facing two powerful forces: a government which had ceased supporting the traditional autonomous Jewish communal structure and its halakhic basis, and a rejection, in part or in whole, on the part of many Jews, of the traditional Jewish lifestyle and its halakhic basis, in favor of various (and sometimes conflicting) modes of westernization. The result was that those Jews who, like Rabbis Kagan and Epstein, supported the traditional Jewish communal structure and lifestyle, often felt themselves literally besieged. Torah, a term which symbolized all that was sacred and precious to them in their culture and lifestyle, had become weakened, even, as Rabbi Kagan stated, "to certain people who are in their own home" (Kagan 1943, 7). How much more so was Torah in trouble among those whom force and circumstance had severed from their home moorings. Therefore, as Eliezer Schweid comments, Rabbi Kagan felt he needed to erect "an embankment and wall in order to prevent [Torah's] collapse, or at least to delay it ... Every moment of postponement [was] precious for at any moment, he was convinced, salvation will arrive from the heavens and the community will be firmly established" (Schweid, 14).

3 It was also published under the name Mahane Yehuda (Vilna: Mats, 1881). This paper utilizes Kagan 1943.

4 This paper utilizes Kagan 1893. There is an English translation, entitled The Dispersed of Israel (New York: Aaron Kagan, 1951) as well as a French translation Nid'hei Israel (France: ADET, 1994). All translations found in this article, however, are mine. 
As part of its program to deal with the problem it perceived in its Jewish community, the Russian government had, in the nineteenth century, embarked on a policy of drafting Jews into its army, initially with clearly assimilationist and conversionist motives (Stanislawski 1983, 13ff.). Though by the latter part of the nineteenth century the conversionist motive of the Russian government was less prominent, and Jewish soldiers were, at least in some times and places, given some facilities for observing their faith, ${ }^{5}$ it was still clear that a significant number of young Russian Jews had been, and would be taken from their homes and thrown into a milieu which militated against their observance of Jewish law and tradition. As well, partially as a result of Russian governmental policies which discriminated against Jews, and partly due to the extraordinary economic opportunity which existed in other countries, Jews in the Russian Empire as well as the other Eastern European countries were driven to emigrate in huge numbers in the four decades prior to the First World War. ${ }^{6}$ Those Jews who left their established communities for either cause were by no means the best equipped to deal with the challenges to their faith and way of life inherent in their new surroundings. Moreover, they faced their legal and moral dilemmas with little or no rabbinic guidance. It was a situation which seemed to Rabbi Kagan fraught with danger to the continuity of Judaism as traditionally understood. His response was to create an halakhic guide that was accessible and authoritative; that would answer burning questions and restore faith. The results of his work were Mahane Yisrael and Nidhe Yisrael. While it is true that the situation of Jewish soldiers in the Russian army and Jewish emigrants to exotic locales was not exactly the same, it was sufficiently so that Rabbi Kagan was able to recycle a large amount of material from Mahane Yisrael in Nidhe Yisrael. ${ }^{7}$ We may therefore examine the two works in tandem.

The basic premise that both works share is that contemporary Jews were facing an unprecedented challenge to the basic structure of Judaism as it had been known and practiced in Eastern Europe because of the removal of large numbers of Jews from their previous communal moorings.

5 Stanislawski 1988b. It should be noted that Rabbi Kagan in Mahane Yisrael throughout assumes that Judaic observance in the Russian army may be difficult, but far from impossible.

6 On the nature of this immigration, and particularly the religious context, see Gartner, 25-43. Gartner discusses Nidhe Yisrael on pp. 33-34. Cf. also Sarna 1981.

$7 \quad$ Rabbi Kagan acknowledges this in his introduction to Kagan 1893, p. 11. 
Soldiers were being stationed away from established Jewish communities ${ }^{8}$ (Kagan 1943, 7, 183), while large numbers of Jewish emigrants were settling in "far off America" (Kagan 1943, 7), Africa, Argentina, and other lands having no established Jewish community. ${ }^{9}$

In analyzing this phenomenon, Rabbi Kagan, though he was no sociologist, had a firm grasp of the influence of peer pressure causing the decline of Torah in his world. He correctly pointed out that in previous generations, when he considered religious observance in the community as a whole to have been at a high level, it was even difficult for those Jews who had "corrupted hearts" to defy such basic things as the Sabbath laws in public (Kagan 1893, 36-37). He was equally correct in his observation that in the present day Jews were not being forced to abandon their Torah by cruel taskmasters (Kagan 1893,8). The Jews were instead being mocked and shamed (Kagan 1893, 88) into non-observance of Torah norms, mainly by other Jews (Kagan 1943, 40-41, 226, 273). Under such conditions, only specially motivated "God-fearing" Jews could resist the pressure and remain true to their traditional lifestyle (Kagan 1893, 288; Robinson 1985).

This situation was exacerbated by a moral breakdown among the Jews. Rabbi Kagan meant this, first of all, in a very literal sense. Jewish young men away from home and its influences and restraints were, he felt, naturally subject to temptations of a sexual nature. At home, as Rabbi Kagan put it, "there is no need of much moral exhortation [musar]" to avoid sexual transgression (Kagan 1943, 120). But given the conditions surrounding Jewish recruits into the Russian army, Rabbi Kagan was of the opinion that they would be better off married before they joined the army because "his [evil] inclination will not dominate him so much [if] he has one [in relation to] whom to be ashamed" (Kagan 1943, 180).

Rabbi Kagan thus chose in his moral exhortation to emphasize the factors which would connect those "disconnected" Jews to the established Jewish communities they had left. However, even in these communities, walls that had long kept ordinary Jews within the parameters of tradition had been breached. In particular, Rabbi Kagan pointed to factories as institutions in which the sexual mores which had traditionally kept Jewish men and women apart had broken down. For Rabbi Kagan, the mingling of the sexes in these factories had led to sexual promiscuity, to couples

8 There is a clear implication that even should the soldiers desire it, contact and aid from established Jewish communities would be at times difficult to establish.

$9 \quad$ Kagan 1893, p. 21 speaks of "the ends of the earth." Cf. also pp. 5, 7, 13. 
living together unmarried and, ultimately, even to infanticide (Kagan $1943,130,148)$. The collapse of the traditional structure of Jewish marriage also led to a growing, and disturbing, phenomenon of intermarriage (Kagan 1943, 152).

Even for those individuals who retained their faith in God and His Torah, and who had thus not as yet progressed so far as these dissolute Jews in their moral decline, there was, for Rabbi Kagan, evidence of a widespread halakhic laxity. ${ }^{10}$ In Rabbi Kagan's depiction, this laxity stemmed from several sources. Jews entering a new and strange environment naturally desired to establish a closer relationship with the people of their new country, especially since so many of them made their living peddling goods from door to door (Kagan 1893, 6). This meant that many of them might feel embarrassment at performing Judaic rituals, such as wearing their tefillin, in non-Jewish homes (Kagan 1893, 54, 57). This did not mean that such people had completely left the fold. On the contrary, Rabbi Kagan expected that there would be some residual fulfillment of the commandments of the Torah in the immigrant generation (Kagan 1893, 79). Despite this residual observance, however, the children of this generation of immigrant Jews would not adhere to even this level of residual observance (Kagan 1893, 8, 79). That is because succeeding generations of Jews in far off lands harbored a new attitude toward the fulfillment of the Torah's commandments. Some would feel that the fulfillment of the commandment of giving charity enabled them to ignore the rest (Kagan 1893, 9). Others felt, in a similar way, that the commandment to make the Torah beautiful, fulfilled by actions such as building ornate synagogues, obviated other forms of observance (Kagan 1893, 29). Still others would not entertain the idea that the system of halakhic commandments was absolutely binding upon them because God had so ordained. Rather they took the view that the commandments were either simply an essentially voluntary Jewish custom, or else understood them as rabbinically-imposed stringencies which could be ignored if there was a need to do so (Kagan 1893, 10, 170-171). As Rabbi Kagan pointed out, this was particularly true in the case of women's obligation to immerse themselves in a mikveh, which was being nearly universally ignored. ${ }^{11}$

10 Kagan 1893, 26. For a description of the sort of compromises referred to, see Morawska.

11 Kagan 1893, 256, 258. On this issue as discussed by a North American Orthodox rabbi, see Rosenberg. 
Another reason for Rabbi Kagan's fear for the future of the Jewish emigrants was that he discerned major and fundamental changes in the traditional pattern of Jewish education in these far off communities (Kagan $1893,108)$. These changes meant that, at best, boys would advance in their Jewish education only to the study of the Pentateuch, with no serious study of rabbinic texts (Kagan 1893, 102). At worst, the Jewish education received by the younger generation would not even advance to the level of reading the Bible, but rather contented itself with mastering the skill of reading the prayer book, and hearing Bible stories (Kagan 1893, 106, 119). Even worse, this sort of Jewish education was considered far inferior by both parents and children to the mastery of secular studies in general schools, which involved as a corollary friendships with gentile children. ${ }^{12}$

What solution, if any, did Rabbi Kagan offer his readers? While his call to his readers to either not emigrate to these places, or, if already emigrated, to attempt to return home to Eastern Europe are the best known of his statements on the subject (Kagan 1893, 288, 290; Gartner), they are far from the sum total of his suggestions. First of all, he called for a renewed, vigorous rabbinical leadership for these communities. In an "open rebuke" [tokheha megula] he challenged the Jewish communities of the far off lands to appoint qualified rabbis to leadership posts, and not merely cantors and ritual slaughterers as hitherto (Kagan 1893, 121, 167-168). Secondly, he called for the establishment of new Jewish schools [Talmud Torah], which would enable their students to study rabbinic texts (Kagan 1893, 119).

Finally, and most fundamentally, he offered his books. They offered their readers, whether in Hebrew or Yiddish, access to both moral exhortation and relevant halakhic knowledge in a format which was designed to be both authoritative and accessible. Most importantly, it is clear that Rabbi Kagan had written both Mahane Yisrael and Nidhe Yisrael because he had been convinced that the Jews whose difficulties he was describing were not going to find the help they required in the halakhic sources hitherto available.

For Eastern European Jews of this era, the halakhic code which was most authoritative was Rabbi Joseph Caro's sixteenth century Shulhan Arukh as emended for Ashkenazic Jews by Rabbi Moses Isserles and interpreted by generations of learned commentators. However, as Rabbi

12 Kagan 1893, 261. On this issue as reported by an Eastern European immigrant to Canada, see Robinson 2004. 
Kagan baldly stated, it was not practical for the average Jew to use it as a guide to halakhic observance. As he stated in Mahane Yisrael, "For it[s utilisation] one needs great investigation [skills] to examine the sources of the law and the [opinions of the] latter[-day halakhic authorities]." "That is why," he went on, "I found myself obliged to arrange the laws from scholars and books" (Kagan 1943, 8), especially in matters of frequent practice (Kagan 1943, 39).

The idea that the Shulhan Arukh did not represent a practical guide to Jewish law for ordinary Jews was not new. It had been recognized for some time prior to Rabbi Kagan's late- nineteenth century attempts to create such a practical guide. He was preceeded in the nineteenth century by two notable attempts to create a genuine halakhic guide for laypeople. They were, as previously mentioned, Hayyei Adam and Kitzur Shulhan Arukh. Rabbi Kagan, in both Mahane Yisrael and Nidhe Yisrael, positively recognizes Hayyei Adam, and recommends its study to his readers (Kagan 1893, 199; Kagan 1943, 44), inviting them to study it in groups (Kagan 1893, 11). He passes over Kitzur Shulhan Arukh in complete silence. ${ }^{13}$ Though it is difficult to argue from silence, it is inconceivable that a halakhic scholar like Rabbi Kagan, preparing a popular halakhic guide, would be unaware of Rabbi Ganzfried's popular work. It is more likely that this lack of mention is a function of his critical disapproval combined with the principle, which he took pains to inculcate in numerous works, to avoid comments which would be harmful to fellow Jews (Kagan 1973).

Rabbi Kagan does not formally recommend group study of his own works. However, if his own modesty perhaps prevented him from doing so, he certainly allowed the printing of a rabbinic letter of approbation introducing Nidhe Yisrael which recommends the study of that work by groups of Jews since it contains an ideal combination of both halakhic information and moral exhortation (Kagan 1893, 3-4). Indeed, the reason that Nidhe Yisrael did not in the end become a more popular and wellknown book which was widely adopted for group study, is indicated in another of the printed rabbinic approbations for Nidhe Yisrael, which makes a play on the words Mishnah Berurah, the title of Rabbi Kagan's halakhic

13 In this context, it is perhaps significant to note that there exist several editions of Kitzur Shulhan Arukh Ganzfried's which are corrected according to the rulings of Mishnah Berurah. One, edited by David Dablitsky, was published in Bnei Brak in 5738 [1977], and another, by an anonymous editor, was published in Jerusalem in 5759 [1999]. 
popularization which he had began publishing in 1883, shortly after he had published Mahane Yisrael. It was, in fact, the immense influence and popularity of Mishnah Berurah which eclipsed Rabbi Kagan's former attempts at halakhic popularization.

In conclusion, having understood the context in which Rabbi Kagan was writing and researching his Mishnah Berurah, we are in a better position to appreciate his statement in his introduction to that work (Kagan 1979, volume 1,5). There, he states that the essential part of a Jewish man's daily study should be halakhah, because it is the observance of the laws of the Torah that will enable him to merit the life of the world that is coming ['olam $h a-b a^{\prime}$ ]. Few, however, engage in this study because the Shulhan Arukh is like a sealed book. In contemporary times, Rabbi Kagan felt, it is too difficult to engage in this research while, moreover, the zeal to do so has lessened [nitma'atu ha-levavot].

Rabbi Kagan firmly believed that he lived in the immediate premessianic generation (Kagan 1893, 36-37). He further felt, however, that the coming of the messiah was dependent upon the observance of the Torah even by those Jews who were going to the ends of the earth. It was therefore incumbent upon him to do his utmost to ensure that Torah was strengthened and preserved. All of his many and varied books seem intent upon fulfilling this task.

Part of the hagiography surrounding Rabbi Kagan is a story which has him state that, if he were younger, he himself would have taken the responsibility of going to America and providing it with rabbinic leadership (Yoshor, 342). Though he did not do so personally, it is a fact that his writings and reputation for saintliness did ultimately arrive there to constitute a discernable formative factor in contemporary Orthodox and Ultra-Orthodox society.

\section{References}

Blidstein, Gerald 1995. “R. Menahem Ha-Meiri: Aspects of an Intellectual Profile," Journal of Jewish Thought and Philosophy 5.

Eckman, Lester 1974. Revered By All: the Life and Works of Rabbi Israel Meir Kagan B'Hafets Hayyim (1838-1933). New York: Shengold.

Elazar, Daniel, Michael Brown and Ira Robinson 2003. Not Written in Stone: Jews, Constitutions, and Constitutionalism in Canada. Ottawa: University of Ottawa Press.

Elon, Menachem 1978. Jewish Law: History, Sources, Principles [Hebrew] second, enlarged edition. Jerusalem: Magnes Press. 
Fishbane, Simcha 1991. The Method and Meaning of the Mishnah Berurah Hoboken: Ktav.

Friedman, Jack E. 1997. “Rabbi Ganzfried's Two Million Kitzurs,” Judaism 46.

Gartner, Lloyd P. 1987. "Jewish Migrants en Route from Europe to North America," in Moses Rischin, ed. The Jews of North America Detroit: Wayne State University Press.

Haas, Peter J. 1996. Responsa: Literary History of a Rabbinic Genre. Atlanta: Scholars Press.

Kagan, Israel Meir 1893. Nidhe Yisrael. Warsaw.

1943. Mahane Yisrael. New York.

1973. Hafetz Hayyim; Shemirat ha-Lashon. Jerusalem.

1979. Mishnah Berurah. Jerusalem: Mekhon Mekor ha-Halakha.

Katz, Jacob 1998. Divine Law in Human Hands: Case Studies in Halakhic Flexibility Jerusalem: Magnes Press.

Morawska, Ewa 1996. Insecure Prosperity: Small Town Jews in Industrial America, 1890-1940. Princeton: Princeton University Press.

Robinson, Ira 1985. "Those Who Fear the Lord: An Elite Within Orthodox Jewry," unpublished paper presented at the Canadian Society for the Study of Religion.

2004. “The Jews in Canada (in North America): an Eastern European View of the Montreal Jewish Community in 1884," Canadian Jewish Studies Chapbook Series No. 1. Montreal.

Rosenberg, Yudel 1913. Mikveh Yehuda. Toronto.

Sarna, Jonathan 1981. “The Myth of No Return: Jewish Return Migration to Eastern Europe, 1881-1914," American Jewish History 71.

Schweid, Eliezer 1977. Orthodoxy and Religious Humanism [Hebrew]. Jerusalem: Van Leer.

Soloveitchik, Haym 1990. The Use of Responsa as a Historical Source [Hebrew]. Jerusalem: Mercaz Zalman Shazar.

- 1999. "Responsa: Literary History and Basic Literacy," AJS Review 24.

Stanislawski, Michael 1983. Tsar Nicholas I and the Jews: the Transformation of Jewish Society in Russia, 1825-1855. Philadelphia: Jewish Publication Society.

1988a. For Whom Do I Toil?: Judah Leib Gordon and the Crisis of Russian Jewry. New York: Oxford.

- 1988b. Psalms for the Tsar: A Minute-Book of a Psalms Society in the Russian Army, 1864-1867. New York: Yeshiva University Library.

Tchernovitz, Chaim 1946-1947. Toldot ha-Poskim New York: 3 volumes.

Twersky, Isadore 1967. "The Shulhan Arukh: Enduring Code of Jewish Law," Judaism 16.

Yoshor, Moses 1952. The Chofetz Chaim: the Life and Works of Rabbi Yisrael Meir Kagan of Radin. New York: Mesorah.

Zipperstein, Steven 1999. Imagining Russian Jewry: Memory, History, Identity. Seattle: University of Washington Press. 


\section{THE BOLDNESS OF}

A HALAKHIST

An Analysis of the Writings of

Rabbi Yechiel Mechel Halevi Epstein

The Arukh Hashulhan 
